\title{
Studying the Flexural Behavior of Reinforced Concrete Beams under the Effect of High Temperature: A Finite Element Model
}

\author{
Hamadallah Al-Baijat ${ }^{1 *}$, Mohammad Alhawamdeh ${ }^{2}$, Aya Khawaldeh ${ }^{3}$ \\ 1 Department of Civil Engineering, Faculty of Engineering, Tafila Technical University, P. O. Box (179) Tafila \\ 66110 , Jordan \\ 2 Department of Civil Engineering, Faculty of Engineering, Tafila Technical University, P. O. Box (179) Tafila \\ 66110 , Jordan \\ ${ }^{3}$ Department of Civil Engineering, Faculty of Engineering, Jordan University of Science and Technology, P. O. \\ Box (3030) Irbid 22110, Jordan \\ * Corresponding author's e-mai: albaijath@yahoo.com, hamadallah@ttu.edu.jo
}

\begin{abstract}
The strength of concrete elements can be greatly affected by elevated temperature as in fires, and so a great concern must be taken regarding its behavior under such condition. In this paper, a finite element model was built up using ABAQUS software to investigate the flexural behavior of reinforced concrete (RC) beams subjected to service load under elevated temperature. The beam was simply supported and was loaded at one-third and two-third of span length. The study consisted of three RC beams models; the first model simulated a control beam specimen at ambient temperature $20{ }^{\circ} \mathrm{C}$, while the other two models demonstrated damaged beams specimens according to two high temperatures $400{ }^{\circ} \mathrm{C}$ and $800{ }^{\circ} \mathrm{C}$, respectively. Each RC beam had $2 \mathrm{~m}$ span length, $300 \mathrm{~mm}$ height and $200 \mathrm{~mm}$ width. The steel reinforcement configuration was $3 \phi 16 \mathrm{~mm}$ (Grade 60) main bars at the positive moment region in the beam bottom, $2 \phi 14 \mathrm{~mm}$ (Grade 60) secondary bars at the beam top, and $\phi 10 \mathrm{~mm} / 150 \mathrm{~mm}$ closed stirrups. The model was validated by comparing its results with the theoretical results from ACI code and literature. Several mechanical properties were investigated including concrete compressive strength, modulus of elasticity, and reinforcing steel yielding strength. The test results showed a reduction in the flexural capacity of the $\mathrm{RC}$ beams, tested at $400{ }^{\circ} \mathrm{C}$ and $800{ }^{\circ} \mathrm{C}$, of $17.6 \%$ and $88.2 \%$, respectively, with respect to the control beam. The maximum service load carried by the beam, at one-third and two-third of the span length, decreased by $17.1 \%$ and $88.1 \%$ for the $400{ }^{\circ} \mathrm{C}$ and $800{ }^{\circ} \mathrm{C}$ high temperature, respectively. The results also showed an increase in deflection when the temperature increased due to the loss in stiffness.
\end{abstract}

Keywords: flexural behavior, reinforced concrete beam, high temperature, fire, finite element model, deflection.

\section{INTRODUCTION}

Extreme loading scenarios might influence the durability and solidity of the structural elements. These loadings can be expressed as external loads, external moments, elevated temperature, and any other loads which can affect the structure during the operational lifetime. Concrete as a structural material has relatively high compressive strength, but significantly lower tensile strength, because of that it is usually reinforced with materials that are superior in tension such as steel. Reinforced concrete structures may be exposed to natural fire during their lifetime. Therefore, it is very important to study the behavior of reinforced concrete during and after fire, and also to study the degree of temperature and duration it can endure. The study of real behavior for reinforced concrete structures during and after fire is very important to achieve a high level of safety.

The strength and stiffness of flexural concrete members are decreased during fire exposure depends on many factors including type of exposure, concrete and reinforced steel rebar properties, the 
load level, and boundary conditions [Kodur and Agrawal, 2016]. Kowalski [2010] indicated that concrete mechanical properties are significantly influenced by temperatures above $400^{\circ} \mathrm{C}$ to $500^{\circ} \mathrm{C}$. Huang et al. [1999] indicated that the design against thermal loading in reinforced concrete structures is based on simplistic techniques, which have been created from the standard fire tests that do not take the real behavior of building during a fire. According to Knaack et al. [2011], there is a need for a predictive structural performance based on fire design principles as an alternative to the existing design methodology. The mechanical properties of the structural materials such as different grades of concrete and reinforced steel, the boundary conditions and all types of loading including thermal loading should be taken into design requirements and considerations.

Chen et al. [2006] Performed an experimental study on two different steel grades at elevated temperatures. High strength and mild structural steel used to investigate the mechanical properties, young's moduli and yield strengths at different levels of strain, while the thermal elongation and ultimate strengths for the two steel grades obtained at different values of temperatures. The test showed that the ACI code and some other codes are conservative for temperature increased up to $1000{ }^{\circ} \mathrm{C}$ in terms of yield strengths but unconservative in terms of young's moduli obtained from the case of transient-state tests. Ellingwood and Lin [1991] conducted a research program to investigate the behavior of reinforced concrete beams subjected to fire. Six reinforced concrete beams, designed to ACI 318-11 specifications, with a $20 \mathrm{ft}(6.1 \mathrm{~m})$ span and a $6 \mathrm{ft}(1.8 \mathrm{~m})$ cantilever were tested. Beams were casted using Normal weight concrete and Grade 60 reinforcing rebars, and were divided into two groups. The first group was tested according to ASTM E119 fire exposure of $550^{\circ} \mathrm{F}$ to $1600{ }^{\circ} \mathrm{F}$ high temperatures for four hours, while the second group was subjected to a short duration high intensity (SDHI). At this technique, fire rapidly increased to $1860^{\circ} \mathrm{F}$ for the first $45 \mathrm{~min}$, then rapidly cooled to $600^{\circ} \mathrm{F}$ during $1 \mathrm{hr} 40 \mathrm{~min}$. Test results showed that flexural cracks were developed in the positive moment region of the span after $30 \mathrm{~min}$ of fire, and continued to widen up to $1 / 4$ in through three hours and a half of fire exposure duration. The most important parameter affected by the elevated temperature of the reinforced concrete flexural member, beam, was the reinforcement temperature history.

Most of the previous studies focused on the mechanical properties (concrete compressive strength, steel yeilding strength, and the modulus of elasticity) of concrete and reinforcing steel while avoiding to assess the effect of increasing temperatures. The objectives of this study are to investigate the flexural behavior of RC beams subjected to different elevated temperature and to evaluate the reduction in the beams' bending capacity due to increase in temperature. The design of the RC beams will be conducted according to ACI 318-14 specifications.

\section{METHODOLOGY}

A finite element model were constructed using ABAQUS software to study the structural behavior of reinforced concrete beams subjected to elevated temperatures. The model consisted of a RC beam with $2 \mathrm{~m}$ span length, $300 \mathrm{~mm}$ height, and $200 \mathrm{~mm}$ wide. The steel reinforcement comprised of $3 \phi 16 \mathrm{~mm}$ (Grade 60) main bars at the positive moment region in the beam bottom, $2 \phi 14 \mathrm{~mm}$ (Grade 60) secondary bars at the beam top, and $\phi 10 \mathrm{~mm} / 150 \mathrm{~mm}$ closed stirrups, as shown in Figure 1 . The beam design procedure followed ACI 318-14 specifications. Table 1 illustrates the theoretical design data for the control beam specimen.

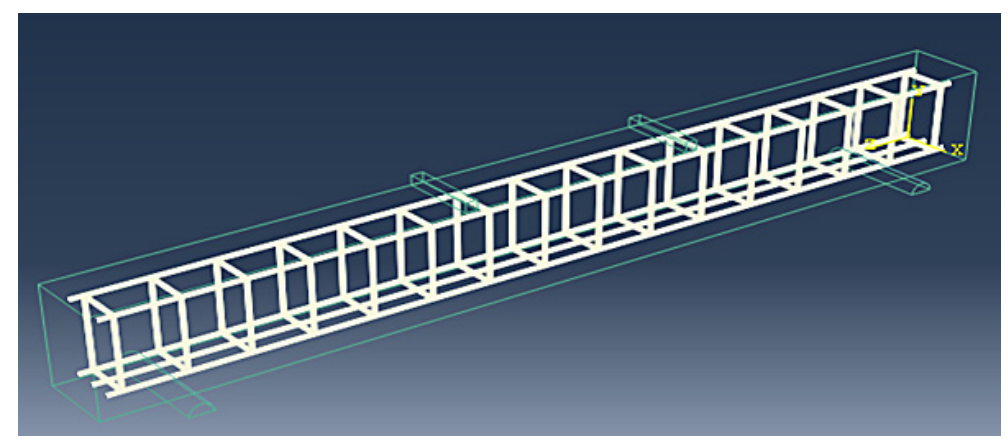

Figure 1. Beam reinforcement details 
Table 1. The theoretical design data for the control beam specimen

\begin{tabular}{|l|c|c|}
\hline Main steel reinforcement (at bottom) & $A_{s}$ & $603.2 \mathrm{~mm}^{2}$ \\
\hline $\begin{array}{l}\text { Secondary steel reinforcement } \\
\text { (at top) }\end{array}$ & $A_{s}{ }^{\prime}$ & $307.9 \mathrm{~mm}^{2}$ \\
\hline Yield strength of steel reinforcement & $f_{y}$ & $420 \mathrm{MPa}$ \\
\hline Concrete compressive strength & $f_{c}^{\prime}$ & $28 \mathrm{MPa}$ \\
\hline Compression depth & $c$ & $51.74 \mathrm{~mm}$ \\
\hline $\begin{array}{l}\text { Yield strain of main steel } \\
\text { reinforcement }\end{array}$ & $\epsilon_{y}$ & 0.002 \\
\hline $\begin{array}{l}\text { Strain in secondary steel } \\
\text { reinforcement }\end{array}$ & $\epsilon_{s}^{\prime}$ & 0.0006807 \\
\hline $\begin{array}{l}\text { Strength in secondary steel } \\
\text { reinforcement }\end{array}$ & $f_{s}^{\prime}$ & $142.947 \mathrm{MPa}$ \\
\hline Nominal moment capacity & $M_{n}$ & $59.505 \mathrm{kN.m}$ \\
\hline Nominal load & $P_{n}$ & $85 \mathrm{kN}$ \\
\hline
\end{tabular}

where:

$f_{c}$, - average uniaxial concrete compressive strength of standard cylinder at 28 days (MPa),

$f_{\mathrm{y}}$ - yield strength of steel reinforcement (MPa),

$f_{\mathrm{s}}$, - strength in secondary steel reinforcement $(\mathrm{MPa})$.

$A_{\mathrm{s}}$ - main steel reinforcement $\left(\mathrm{mm}^{2}\right)$,

$A_{\mathrm{s}}^{\mathrm{s}}$,- secondary steel reinforcement $\left(\mathrm{mm}^{2}\right)$,

$c$ - compression depth (mm).

$\epsilon_{\mathrm{y}}-$ yield strain of main steel reinforcement.

$\epsilon_{\mathrm{s}}$ ' - strain in secondary steel reinforcement.

$M_{\mathrm{n}}$ - nominal moment (moment capacity in $\mathrm{kN} \cdot \mathrm{m}$ ).

$P_{\mathrm{n}}-$ nominal load (load capacity in $\mathrm{kN}$ ).

\section{MODELING}

\section{Concrete}

Concrete damaged plasticity model was used in ABAQUS to simulate concrete behavior in beams. To achieve this model, the strength and the corresponding longitudinal strain of confined concrete were represented by the following relationships [Tsai, 1988]:

$$
\begin{aligned}
& E_{c}=8200 \times f_{c}^{\prime 0.375} \\
& \varepsilon_{c c}=\frac{f_{c}^{\prime 0.25}}{1153} \\
& x=\frac{\varepsilon_{c}}{\varepsilon_{c c}} \\
& r=\frac{f_{c}^{\prime}}{5.2}-1.9 \\
& n=\frac{7.2}{f_{c}^{0.375}} \\
& f_{c c}^{\prime}=\frac{n x f_{c}^{\prime}}{1+\left(n-\frac{r}{r-1}\right) \times x+\frac{x^{r}}{r-1}}
\end{aligned}
$$

$$
\begin{aligned}
& f_{t}^{\prime}=\frac{f_{c c}^{\prime 0.5}}{3} \\
& \varepsilon_{t o}=\frac{f_{t}^{\prime}}{E_{c}}
\end{aligned}
$$

where:

$E_{c}$ is the concrete modulus of elasticity (MPa),

$x$ is the ratio of concrete strains,

$\varepsilon_{c}$ is the longitudinal compressive concrete strain, $\varepsilon_{c c}$ is the maximum confined concrete strain,

$f_{c c}^{c c}$, is the compressive strength (peak stress) of confined concrete,

$f_{t}$, is the tensile strength of concrete,

$\varepsilon_{t O}$ is the tensile rupture strain in concrete,

$n$ is the ratio of the initial tangent modulus to the secant modulus,

$r$ is a factor to control the steepness rate for the descending portions of the stress-strain relation.

These relationships yield the conventional stress-strain diagrams of concrete under compression and tension prior exposure to elevated temperature, as shown in Figures 2 and 3. Under uniaxial tension, the behavior of concrete is linear until reaching the micro-cracking, then mutate by softening response in strain.

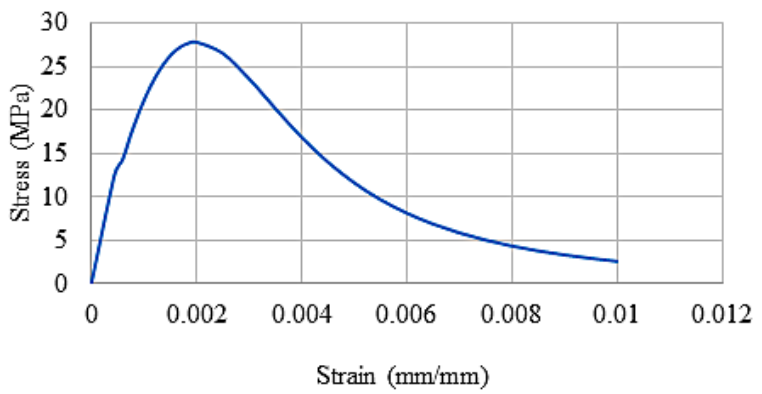

Fig. 2. Typical compressive stress-strain diagram for concrete prior exposure to high temperature

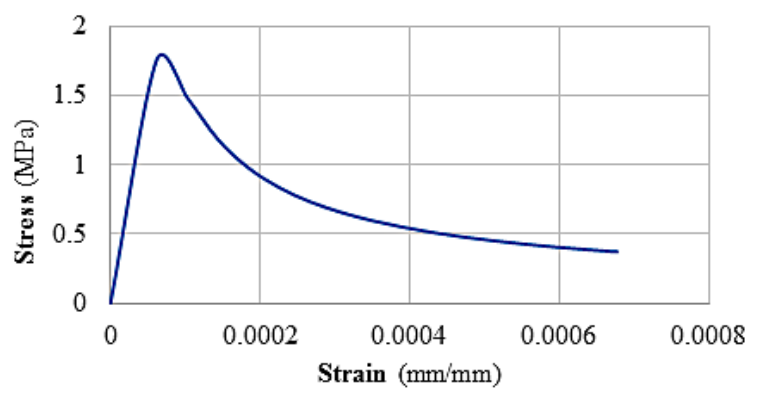

Fig. 3. Typical tensile stress-strain diagram for concrete prior exposure to high temperature 


\section{Steel reinforcement}

The stress-strain curve of the reinforcing steel bar is assumed to be linear elastic up to the yield stress of steel, followed by perfectly plastic behavior. According to Topçu and Karakurt [2008], The yield strength of reinforcing steel bars is influenced by exposure to elevated temperatures. Figure 4 illustrates the behavior of reinforced steel during elevated temperature.

\section{Post heating model}

The post-heating behavior of concrete was characterized using the following equations [Wong, 2011]:

$$
\frac{E_{T}}{E_{o}}=1.0+\frac{T}{2000 \ln \left[\frac{T}{1100}\right]} \quad \text { for } 0^{\circ} \mathrm{C}<T \leq 600^{\circ} \mathrm{C}
$$

$\frac{E_{T}}{E_{o}}=\frac{690\left(1-\frac{T}{1000}\right)}{T-53.5} \quad$ for $600^{\circ} \mathrm{C}<T \leq 1000^{\circ} \mathrm{C}$ where:

$E_{O}$ is the modulus of elasticity at ambient temperature,

$E_{T}$ is the modulus of elasticity at temperature,

$T$ is the elevated temperature.

\section{ABAQUS model}

As previously mentioned, a finite element model using ABAQUS software was carried out to obtain the reduction in beam capacity due to elevated temperature. This research comprised of three reinforced concrete beam models, these models simulated a control beam specimen at ambient temperature $20^{\circ} \mathrm{C}$, and two damaged beam specimens subjected to $400{ }^{\circ} \mathrm{C}$ and $800{ }^{\circ} \mathrm{C}$, respectively. The beam model, loading condition, and mesh are illustrated in Figures 5 and 6 .

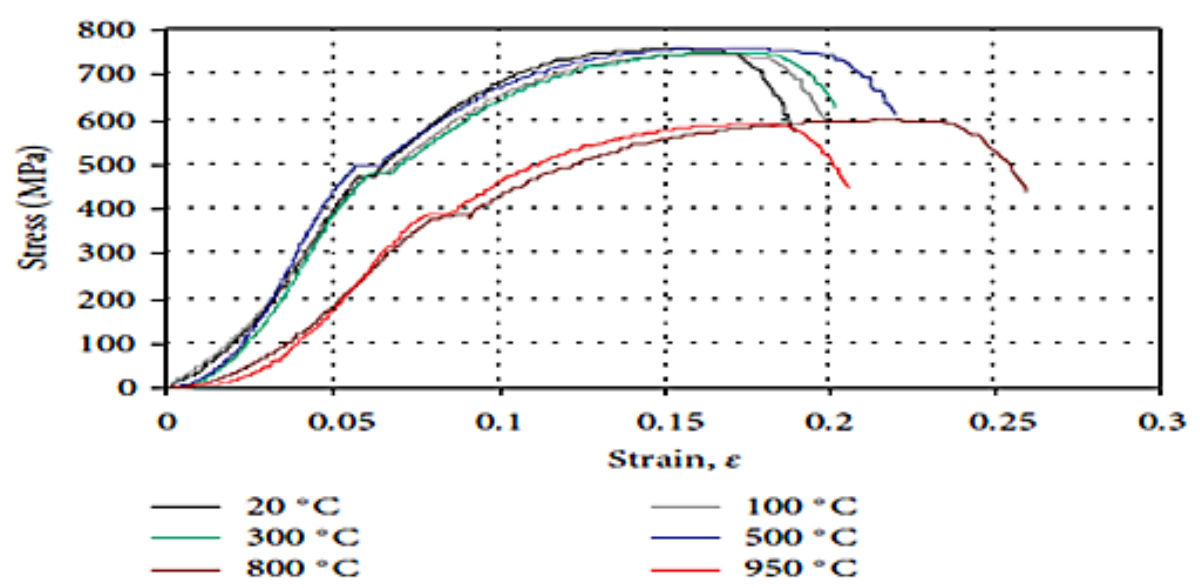

Fig. 4. Stress-strain curve of grade 60 (420 MPa) steel rebar [Topçu and Karakurt, 2008]

a)

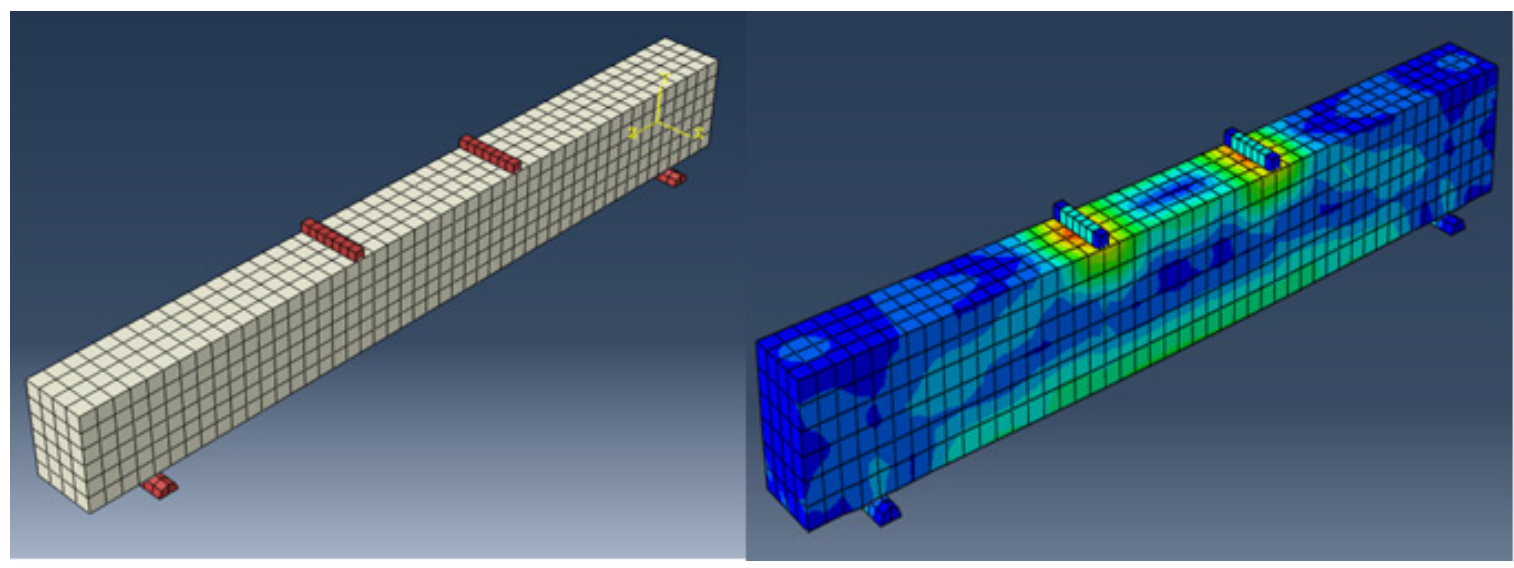

Fig. 5. Beam model with assigned mesh (a) before loading, (b) after loading 


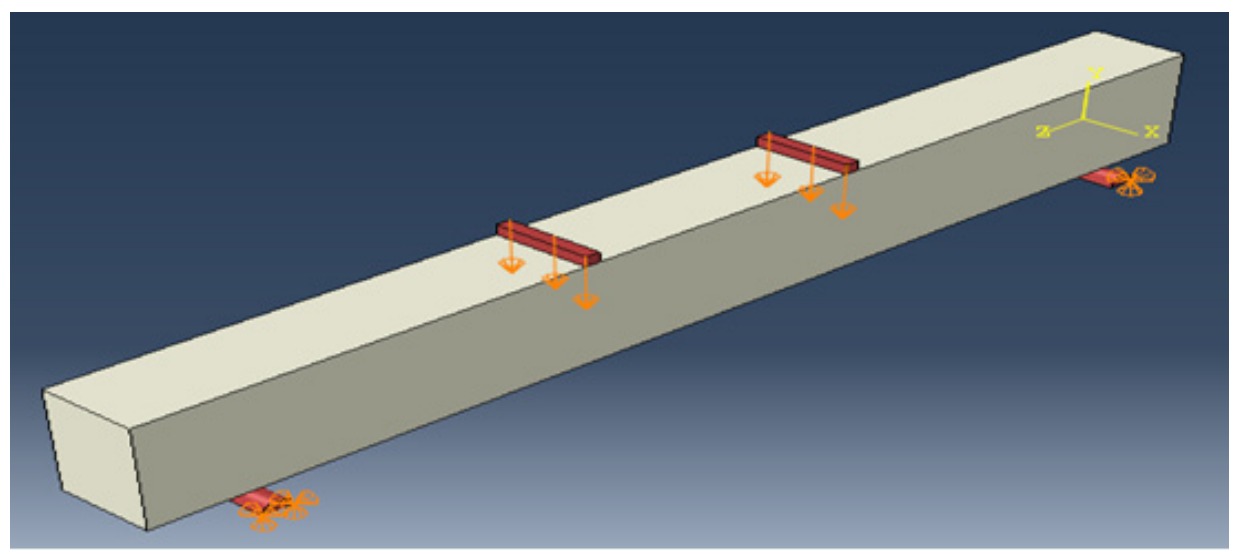

Fig. 6. Boundary and loading conditions used in the beam model (simply supported beam loaded at one-third and two-third of span length)

\section{RESULTS AND DISCUSSION}

After running the model, several parameters were evaluated under different temperature to assess the effect of elevated temperature on RC beams. These parameters included the concrete compressive strength, concrete modulus of elasticity, and steel reinforcement yielding strength. Using these parameters, the flexural behavior of reinforced concrete beams prior and post to elevated temperature exposure was obtained. The reasulted data for both control and heated specimens was used to compare between these two conditions as shown in Table 2.

After comparing unheated and heated parameters, the nominal load, nominal moment capacities, and deflection have been obtained from the model as shown in Table 3 . The table also provide the decrease in capacity and increase in deflection for the heat-damaged specimens.
The relationship between the increasing service load and deflection was monitored along the model running process. Figure 7 shows the great reduction in stiffness while increasing the temperature. It was estimated that the stiffness decreased by $15.4 \%$ and $86.1 \%$ at $400{ }^{\circ} \mathrm{C}$ and $800{ }^{\circ} \mathrm{C}$, respectively, with respect to the control beam. Figures 8 and 9 show the intensive reduction in moment and load capacity, respectively.

\section{CONCLUSIONS}

A finite element model was used to assess the fire behavior of RC beams subjected to increasing service loading. After analyzing the results, the following conclusions were found:

1. The model succeed in describing the behaviour of $\mathrm{RC}$ beams under elevated tempera-

Table 2. Comparison between concrete compressive strength, modulus of elasticity, and steel reinforcement yielding strength prior and post to elevated temperature exposure

\begin{tabular}{|c|c|c|c|c|c|c|c|}
\hline Specimen & $\begin{array}{c}\text { Temperature } \\
\left({ }^{\circ} \mathrm{C}\right)\end{array}$ & $\begin{array}{c}\text { Compressive } \\
\text { strength } f_{c}{ }^{\prime} \\
(\mathrm{MPa})\end{array}$ & $\begin{array}{c}\text { Modulus of } \\
\text { elasticity } E_{c} \\
(\mathrm{MPa})\end{array}$ & $\begin{array}{c}\text { Steel reinforcement } \\
\text { yielding strength } f_{y} \\
(\mathrm{MPa})\end{array}$ & $\begin{array}{c}\text { Decrease } \\
\text { in } f_{c}{ }^{\prime} \\
(\%)\end{array}$ & $\begin{array}{c}\text { Decrease } \\
\text { in } E_{c} \\
(\%]\end{array}$ & $\begin{array}{c}\text { Decrease } \\
\text { in } f_{y} \\
(\%]\end{array}$ \\
\hline Control & 20 & 28 & 28537 & 420 & - & - & - \\
\hline B -400 & 400 & 15.6 & 22953 & 402 & 44.3 & 19.6 & 4.3 \\
\hline B -800 & 800 & 0.3 & 5289 & 198 & 98.9 & 81.5 & 52.9 \\
\hline
\end{tabular}

Table 3. Comparison between nominal capacity $\left(P_{n}\right.$ and $\left.M_{n}\right)$ and deflection of unheated and heated specimens

\begin{tabular}{|c|c|c|c|c|c|c|c|c|}
\hline Specimen & $\begin{array}{c}\text { Temperature } \\
\left({ }^{\circ} \mathrm{C}\right)\end{array}$ & $\begin{array}{c}\text { Nominal } \\
\text { load, } P_{n} \\
(\mathrm{kN})\end{array}$ & $\begin{array}{c}\text { Decrease } \\
\text { in } P_{n} \\
(\%)\end{array}$ & $\begin{array}{c}\text { Nominal } \\
\text { moment, } M_{n} \\
(\mathrm{kN} \cdot \mathrm{m})\end{array}$ & $\begin{array}{c}\text { Theoretical } \\
\text { strength } \\
(\mathrm{MPa})\end{array}$ & $\begin{array}{c}\text { Decrease } \\
\text { in } M_{n} \\
(\%)\end{array}$ & $\begin{array}{c}\text { Deflection } \\
\text { at mid-span } \\
(\mathrm{mm})\end{array}$ & $\begin{array}{c}\text { Increase in } \\
\text { deflection, } \\
(\%)\end{array}$ \\
\hline Control & 20 & 85 & - & 59.92 & 59.505 & - & 8.7 & - \\
\hline B - 400 & 400 & 70.5 & 17.1 & 49.35 & - & 17.6 & 9 & 3.4 \\
\hline B - 800 & 800 & 10.1 & 88.1 & 7.07 & - & 88.2 & 10.2 & 17.2 \\
\hline
\end{tabular}


P-D curve

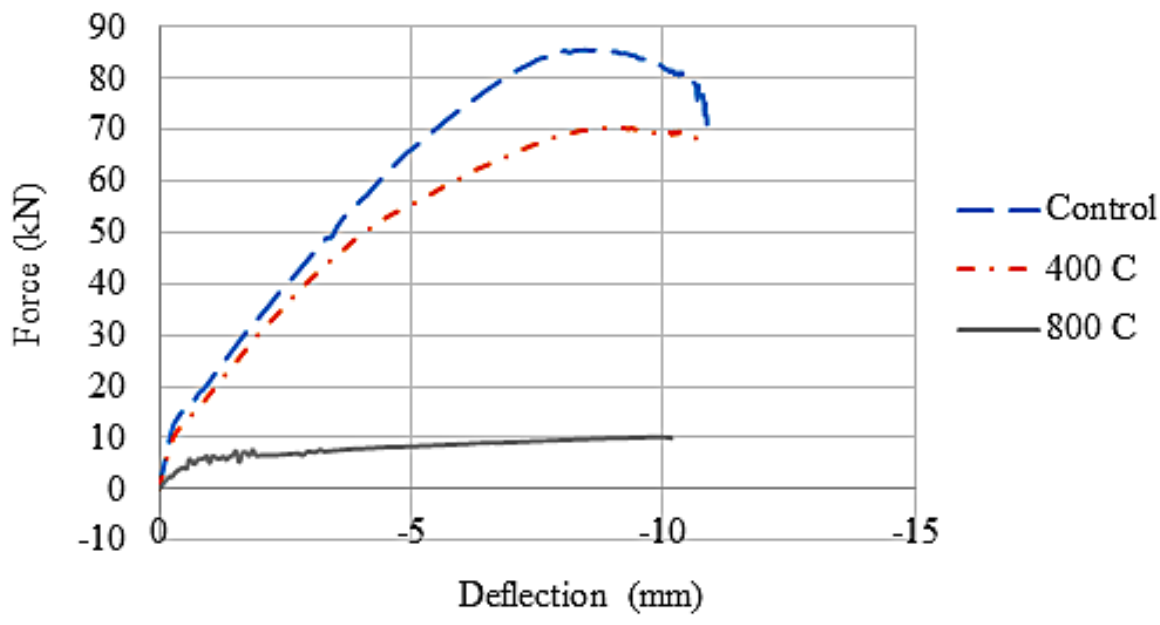

Fig. 7. Load versus deflection at mid-span for different temperature values

Nominal moment capacity

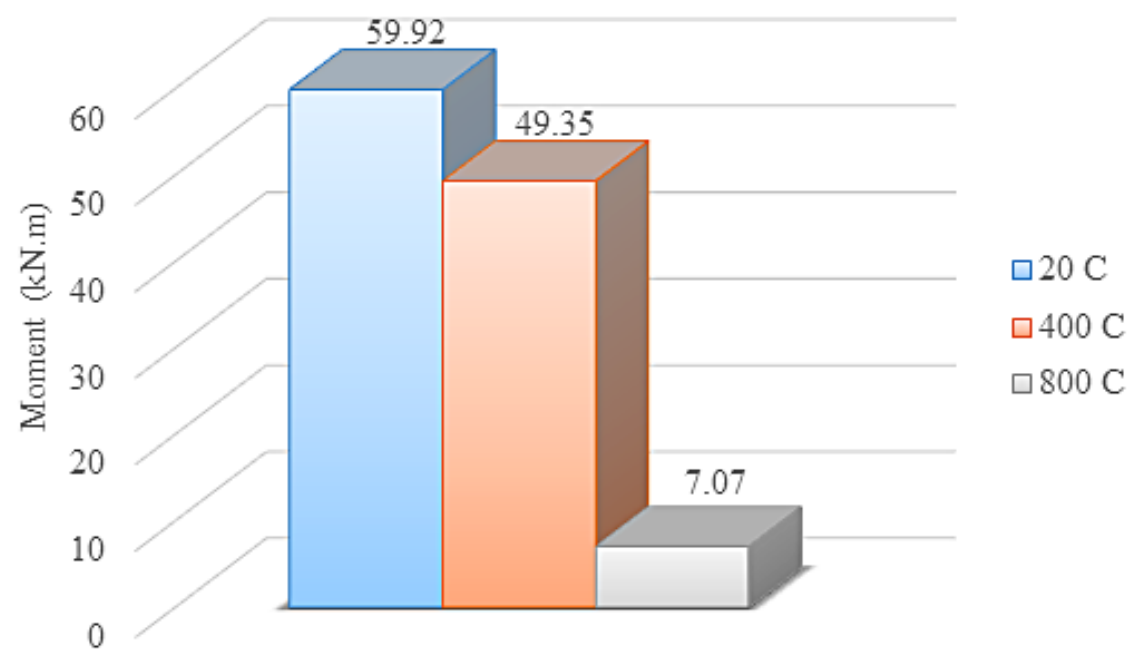

Fig. 8. Moment capacity of the beam for different temperature values

\section{Concentrated Force P values}

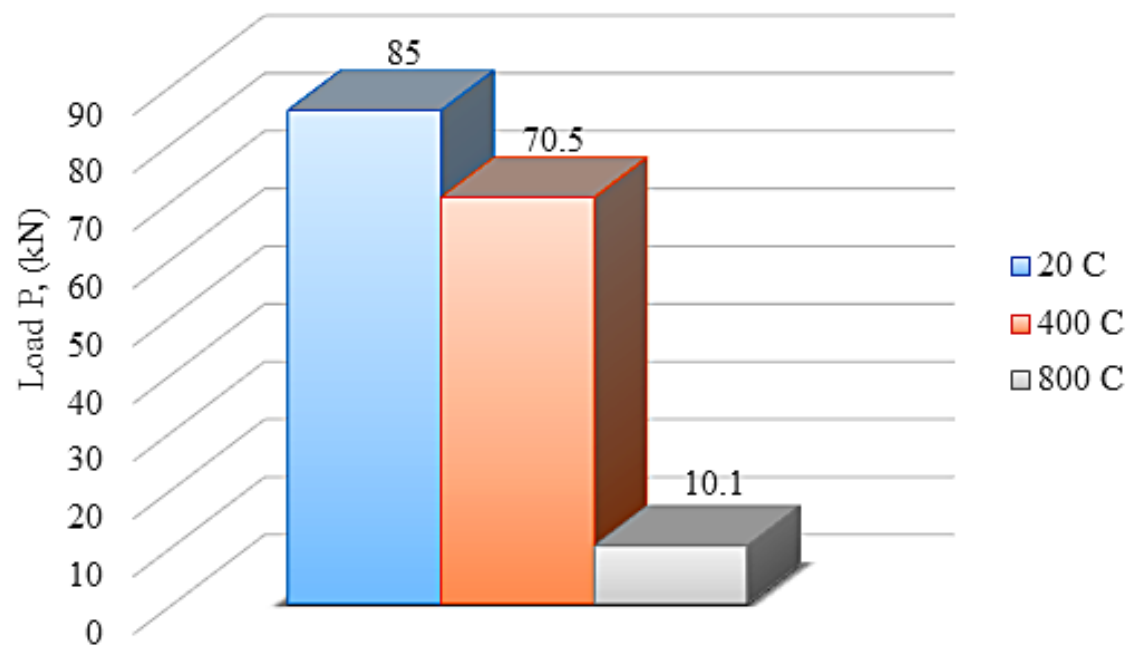

Fig. 9. Load carried by the beam for different temperature values 
ture. It was validated by comparing its results with the theoretical results from ACI code and literature.

2. Steel reinforcement was not affected at $400{ }^{\circ} \mathrm{C}$ temperature $\left(4.3 \%\right.$ reduction in $\left.f_{v}\right)$. While it greatly deteriorated at $800{ }^{\circ} \mathrm{C}(52.9 \%$ reduction in $f_{y}$ ).

3. The concrete lost about $44.3 \%$ of its compressive strength and $19.6 \%$ of its modulus of elasticity at $400{ }^{\circ} \mathrm{C}$. While the reduction severely increased up to $98.9 \%$ in the compressive strength and $81.5 \%$ in the modulus of elasticity at $800{ }^{\circ} \mathrm{C}$.

4. The reduction in beam's flexural capacity was $17.6 \%$ and $88.2 \%$ for the $400{ }^{\circ} \mathrm{C}$ and $800{ }^{\circ} \mathrm{C}$ high temperature, respectively.

5. The maximum service load carried by the beam, at one-third and two-third of the span length, was $85 \mathrm{kN}$. This load decreased by $17.1 \%$ and $88.1 \%$ for the $400{ }^{\circ} \mathrm{C}$ and $800{ }^{\circ} \mathrm{C}$ high temperature, respectively.

6. The maximum deflection (at mid-span) increased by $3.4 \%$ and $17.2 \%$ for the $400{ }^{\circ} \mathrm{C}$ and $800{ }^{\circ} \mathrm{C}$ high temperature, respectively. This was referred to the loss in stiffness as temperature increased.

7. Due to the intensive deterioration in steel's yielding strength, concrete's compressive strength, and modulus of elasticity. The flexural and load capacities decreased, at $800{ }^{\circ} \mathrm{C}$, by $90 \%$ of their unheated values. Under such reduction, the RC beam is entirely destroyed.

\section{REFERENCES}

1. ACI Committee 318. 2014. Building Code Requirements for Structural Concrete (ACI 318M14) and Commentary (ACI 318RM-14). American Concrete Institute, Farmington Hills, MI.

2. Chen J., Young B., and Uy B. 2006. Behavior of high strength structural steel at elevated temperatures. Journal of Structural Engineering, 132(12), 1948-1954.

3. Ellingwood B., and Lin T.D. 1991. Flexure and shear behavior of concrete beams during fires. Journal of Structural Engineering, 117(2), 440-458.

4. Huang Z., Burgess I.W., and Plank R.J. 1999. Nonlinear analysis of reinforced concrete slabs subjected to fire. Structural Journal, 96(1), 127-135.

5. Topçu I.B., and Karakurt C. 2008. Properties of reinforced concrete steel rebars exposed to high temperatures. Research Letters in Materials Science, 2008, 1-4. doi:10.1155/2008/814137

6. Knaack A.M., Kurama Y.C., and Kirkner D.J. 2011. Compressive stress-strain relationships for North American concrete under elevated temperatures. ACI Materials Journal, 108(3), 270.7

7. Kodur V.K.R., and Agrawal A. 2016. An approach for evaluating residual capacity of reinforced concrete beams exposed to fire. Engineering Structures, 110, 293-306.

8. Kowalski R. 2010. Mechanical properties of concrete subjected to high temperature. Architecture Civil Engineering Environment, (2), 61-70.7

9. Tsai W.T. 1988. Uniaxial compressional stressstrain relation of concrete. Journal of Structural Engineering, 114(9), 2133-2136.

10. Wong M.B. 2011. Plastic analysis and design of steel structures. Butterworth-Heinemann, Oxford. 